Гавдида Н. I.

кандидат філологічних наук, доцент

Тернопільський національний технічний університет імені Івана Пулюя

\title{
ЛЕКСИКО-СЕМАНТИЧНІ ЗАСОБИ ВИРАЖЕННЯ МЕНТАЛЬНОСТІ УКРАЇНЦВ У РОМАНІ ПАНАСА МИРНОГО ТА ІВАНА БІЛИКА «ХІБА РЕВУТЬ ВОЛИ, ЯК ЯСЛА ПОВНІ?»
}

У статті аналізуються мовні особливості відтворення ментальності українців у романі Панаса Мирного та Івана Білика «Хіба ревуть воли, як ясла повні?». Зокрема визначено, які саме риси вважаються типовими для украӥнської нації. Увагу зосереджено на лексико-семантичних засобах відображення мислення і світобачення українців у тексті роману.

Ключові слова: ментальність, національна самосвідомість, роман, національний характер, естетизм, антеїзм, емочийність, метафора, епітет, порівняння, портрет, пейзаж, звертання.

В статье анализируются языковые особенности воссоздания ментальности украинцев в романе Панаса Мирного и Ивана Билька «Хіба ревуть воли, як ясла повні?». В частности определено, какие именно черты считаются типичными для украинской нации. Внимание сосредоточено на лексико-семантических средствах отображения мышления и мировоззрения украинцев в тексте романа.

Ключевые слова: ментальность, начиональное самосознание, роман, национальный характер, эстетизм, антеизм, эмоциональность, метафора, эпитет, сравнение, портрет, пейзаж, обращение.

The article deals with the linguistic features expressing Ukrainian mentality in the novel «Khiba revut voly, yak yasla povni» by Panas Myrnyi and Ivan Bilyk. The features which are typical for Ukrainian nation are pointed out. Attention is focused on lexicalsemantic means of thinking and world outlook of Ukrainians in the text of the novel.

Keywords: mentality, national identity, novel, national character, aestheticism, anteyizm, emotionality, metaphor, epithet, comparing, portrait, landscape, reference.

Чисельність праць, спрямованих на дослідження української ментальності, засвідчує прагнення національної спільноти пізнати себе, дати відповідь на одвічне питання смисложиттєвості, котра 
реалізовується в різних формах філософської рефлексії, у тому числі й у художній літературі. Тому актуальність нашої статті зумовлена увагою до проблем національної самосвідомості й самовираження, необхідністю пошуків нових підходів до вивчення мовних засобів представлення ментальності, що становлять особливий інтерес для сучасних напрямів мовознавства. Мета цієї публікації - виявити та описати основні лексико-семантичні засоби вираження ментальності української нації в романі Панаса Мирного та Івана Білика «Хіба ревуть воли, як ясла повні?», адже грунтовної праці, присвяченої цій темі, в Україні ще немає.

Українську ментальність значною мірою сформували геополітичні та історичні особливості, дослідженням яких у різні періоди займались В. Антонович, Ю. Бойко, Д. Донцов, М. Костомаров, П. Куліш, О. Кульчицький, Ю. Липа, І. Нечуй-Левицький, С. Онацький, В. Пачовський, В. Храмова, Д. Чижевський, М. Шлемкевич та ін. Кожен із авторів згаданих досліджень по-своєму інтерпретує бачення поставленої проблеми.

Так, Д. Чижевський найтиповішими рисами українців вважав емоційність, сентиментальність, чутливість, а також індивідуалізм, потяг до свободи та рухливість [Чижевський 1983]. В. Храмова, посилаючись на праці багатьох дослідників (М. Костомарова, І. Нечуя-Левицького, В. Липинського, Є. Онацького, М. Шлемкевича, О. Кульчицького та інших), зауважила, що українська психічна структура вирізняється емоційно-почуттєвим характером, «кордоцентричністю», а це певною мірою зменшує роль національно-вольового компонента в проявах національного характеру. Саме тому українець часто сповнений спокою неминучості та покірності долі [Храмова 1992].

Послідовники Д. Чижевського, погоджуючись, що риси, наведені вченим у «Нарисах з історії філософії на Україні», є типовими для українців, відмічали ще естетизм (Ю. Липа, М. Шлемкевич), прив'язаність до землі, тобто «антеїзм» (Ю. Липа, М. Шлемкевич), а також життєлюбність і життєздатність (М. Шлемкевич). 
Цінним джерелом вивчення ментальності нашого народу $є$ твори літературної класики, які демонструють нам широку галерею образів українців. Тому, аналізуючи роман Панаса Мирного та Івана Білика «Хіба ревуть воли, як ясла повні?», ставимо перед собою завдання з'ясувати, які риси української ментальності притаманні персонажам мовленнєвого полотна, а найголовніше, якими мовними засобами ці риси відображено.

Визначальною рисою української вдачі, що найповніше проявилась у творі, є емоційність. Персонажі роману страждають, плачуть і сміються, кохають і ненавидять. Через авторське мовленні розкриваємо для себе складний внутрішній світ Чіпки, Мотpi, Галі, бачимо панораму людських почуттів та пристрастей. Найчастіше Панас Мирний та Іван Білик передають емоційну наснаженість образу через портрет, глибоко психологізований, насичений метафорами, епітетами, порівняннями. У творі часто трапляються динамічні портрети, які виражають раптові почуття, що охоплюють персонажів: «Дід не зміг далі говорити... Дві гарячі сльози викотилось з його старих жовтих очей і розлилося по карбованому старістю та негодами виду» [Панас Мирний та Іван Білик 1981: 58], ${ }^{1}$ «...стояв Чіпка навколішки і молився... прокльонами. Сльози блищали в його очах...» [239], «...личко (Галі- Н.Г.) ...від такої несподіваної тривоги зашарілось, здається - пашіло полум'ям» [66].

Для того, щоб передати емоційність персонажів, письменники вдаються до використання тропів, зокрема, порівнянь, епітетів, метафор та персоніфікації. Цікаво, що Панас Мирний та Іван Білик найчастіше застосовують порівняння для передачі негативних емоцій, таких як страх, нудьга, зневіра, туга, розпач. Ось як змальовують письменники внутрішній стан Чіпки, коли він дізнається від діда, як його батька спровадили в москалі: «Чіпка поплентався... позад отари, немов п'яний, наче учадів...» [Панас Мирний та Іван Білик 1981: 60], «Він сидів зажурений, німий, як стіна... Як

1 Далі цитуємо за цим виданням, вказуючи в дужках сторінку. - Н. Г. 
колода, повалився на лаву, та тільки стогнав» [Панас Мирний та Іван Білик 1981: 61].

Іноді автори роману послуговуються порівняннями, які перегукуються із фольклорними, а особливо - 3 народнопісенними. Такі тропи не лише сприяють емоційній насиченості образу, а й підносять його до типових ідеалів нашого народу щодо краси, материнської любові: «Уляна зардіється, як макова квітка» [Панас Мирний та Іван Білик 1981: 112], «Уразили такі гадючі слова материне серце. Як підстрелена горлиця тіпається-б'ється, тихо туркоче й стогне: так мати затіпалась на печі в куточку...» [184].

Характерною ознакою творчої майстерності авторів роману $\epsilon$ поєднання таких засобів виразності, як порівняння і метафора, які іноді настільки влучно підібрані, що створюють враження єдиного цілого: «Брови його насупились; коло серця, мов чорна гадина, обвився жаль...» [187]. Найчастіше автори роману використовують метафори для передачі емоційності образу головного героя: «Після того - не пізнати Чіпки: з личя спала давня туга, очима не виглядав смуток...» [70], «Його обдало холодом, потім обсипало жаром...» [174], «Закипіло його серие, заболіла душа... Обняло його зло нелюдське. Серие в його вило; душа палала...» [231].

Емоційність українців відображають влучно підібрані епітети, які увиразнюють характерну властивість певного явища чи поняття. «Стилістична функція епітетів полягає в тому, що вони дають змогу показати предмет зображення з несподіваного боку, індивідуалізують якусь ознаку, викликають певне ставлення до зображуваного» [Пономарів 1992: 46]. Ці образні означення допомагають читачам 3'ясувати, які саме емоції заполонили серце героя на певному етапі твору, а також сприяють виявленню авторського ставлення до персонажів. Зокрема, епітети «радий та веселий» [71], вжиті щодо Чіпки, вказують на позитивні емоції, які охоплюють його після зустрічі з Галею. А художні означення «сумний, блідий, грізний» [256], якими характеризують Вареника Панас Мирний та Іван Білик, допомагають зрозуміти: почуття, що заполонили героя 
твору, ніяк не радісні, безжурні, а тривожні й неприємні. Художнє означення «гіркі сльози» [353], якими заливалась Мотря у відповідь на образу сина, сконденсовують у собі величезне материнське горе, відчай, біль від втрати сина, сором перед людьми за нього.

У романі також наявне ключове слово «серце». Воно допомагає нам краще зрозуміти кордоцентризм української вдачі, який тісно пов'язаний із поняттям емоційності. Дослідники ментальності українців неодноразово відзначали, що представники нашої нації в житті частіше керуються серцем, а не розумом, тобто чинять за покликом серця.

Таким типовим українцем є Грицько Чупрун: «Довго він міркував (Грицько - Н. Г.) собі, перебирав у думиі всіх дівчат на селі, та сам незчувся: як і коли закохався в сусідчину наймичку - веселу, моторну й робочу дівчину, хоч й невелику красулю... Христя -молода, весела, щебетуха, працьовита дівчина... Забув Грицько про великий посаг, який думав затягти за жінкою; годі думати про якусь незвичайну красу, - давай личятися та женихатися з Христею...» [80].

Ключове слово «серце» трапляється в творі у найрізноманітнішому поєднанні слів, що допомагає майстерніше передати всю глибину внутрішніх переживань персонажів. «Ви мене привітали, як рідні; моє серие, мою душу одігріли...» [197], «Чіпка пізнав голос. Сміх над його молитвами, над його сльозами, товариська зрада, докора - разом кинулись йому в голову, схопили за серие...» [240], «Чіпка мовчав, не озивався; серие його одходило» [241], «Згадаю, серие розривається, душа болить...» [244], «Душа мліла й боліла, - помстою; серие гукало - оддячити...» [245], «Серие в неї замеміло... на душі так погано, коло серия щзось в’ється так...» [247], «Серие в неї щеміло, боліло...» [248].

Цікавим вираженням емоційності у романі є звертання. «Галочко» [271], «Любо моє!.. кохання моє!» [272], «моя горличко» [273], «рибонько моя» [276], - звертається Чіпка до коханої дівчини. Важко навіть повірити, що ця ж людина стане вбивцею, катом невинних жертв. 
Виокремимо й такі риси української вдачі: сентименталізм, чутливість і ліризм, - які об'єднаємо в одне поняття - артистизму. Українській душі притаманні замилування навколишньою красою, безмежна любов до пісні, яка є вірною супутницею і в радості, і в горі. Основним мовним засобом вираження артистизму українців стала авторська мова. «Вийняв сопілку, послинив дірочку, свиснув раз, удруге - $і$ зачав „Вівчарика”. Гучно-гучно загула сопілка на все поле, немов хто заспівав жалібно...» [52].

Для українців типовою, за М. Шлемкевичем, є також така риса, як естетизм. Вона проявляється у любові нашого народу до чепурних, побілених вапном жител, до вишневих садків, пісень соловія. Панас Мирний та Іван Білик намагаються передати цю рису національної вдачі з допомогою таких прийомів, як портрет та пейзаж. Письменники зосереджують увагу читача на вбранні своїх персонажів, змальовуючи кольорову гаму частин народного одягу, дають йому високу естетичну оцінку. Складається враження, що автори милуються своїми персонажами.

Через портретні характеристики виявляється ще одна риса української вдачі - оптимізм, життєрадісність. На неї вказує часте використання епітета «веселий» та дієслова «усміхатися»: «... глянула на його веселими очима, усміхнулась свіжим личком... Сама невеличка ... з веселою усмішкою на виду» [21], «Не ск-а - ж-у! одмовила вона (Галя - Н.Г.) нарозтяг, осміхаючись... стала... озирнулася; осміхнулась...» [22].

Прийомом вираження естетизму українців у романі $є$ пейзажі, які спонукають до висновку, що краса природи значною мірою впливає на формування української вдачі, основних рис ментальності нашої нації. У тексті роману знаходимо описи села, котрі вказують на любов нашого народу до всього красивого, охайного, чистого. Таке враження підсилює і часте вживання епітета «чепурний». «Дівчини не видно, - тільки зеленіли то там, то там, обложсивиись полями, хутірські сади, як розкішні квітники, а між зеленою листвою вишняку, груш, слив та яблунь біліли чепурні 
хаточки» [23]. «Хата, хоч старенька, та чепурна, біла, - видно, біля неї ходили хазяйські руки; двір виметений, чистий; огорожа ціла, хоч і низенька, а ворота дощзані - хрещзаті» [23]. «I в хаті в них стало чепурніше, ясніше... I зокола хата обмазана, хоч рудою глиною, та все ж рівненько...» [54].

У зовнішньому вигляді осель, старанно відгороджених від сусідів, проявляється індивідуалізм української вдачі. Ця особливість ментальності представників нашої нації нерозривно пов'язаний із землею, формуючи антеїзм - прив'язаність до землі. Без неї жоден селянин не уявляв свого життя. Ось як говорить про це Чіпка: «Земля!.. Хліб родить, як коло неї походиш; хазяӥном робить... Сказано - земля! А без землі-усе пропало... усе!» [177].

Прив'язаність до землі як одвічної й найбільшої цінності виливається у хліборобський світогляд, типовим виразником якого є Грицько Чупрун. Його життєвий ідеал - хата тепла, жінка-любка та маленька дитинка, тобто тихе сімейне щастя в любові та злагоді.

Роман «Хіба ревуть воли, як ясла повні?» є надзвичайно цінним джерелом вивчення української ментальності, оскільки персонажі цього твору виявляють такі риси національної вдачі, як емоційність, ліризм, сентиментальність, естетизм, оптимізм, антеїзм, індивідуалізм. Панас Мирний та Іван Білик творчо підійшли до змалювання образів, використовуючи для передачі складних емоційних переживань персонажів психологізовані портрети, метафори, порівняння, епітети, персоніфікації, звертання, ключові слова. Завдяки лексико-семантичному багатству тексту авторам вдалося відобразити типові риси українського національного характеру.

\section{БІБЛІОГРАФІЯ}

Бойко 1992 - Бойко Ю. Шлях нації /Ю.Бойко. - Париж-Київ-Львів, 1992. - 126 с. Донцов 1991 - Донцов Д. Дух нашої давнини /Д.Донцов - Дрогобич, 1991. - 342 с. Костомаров 1906 - Костомаров М. Дві руські народности /М.Костомаров. - КиївЛяйпціг, 1906. - $111 \mathrm{c.}$

Коцюба 2010 - Коцюба О. Мовні засоби відображення ментальності українського народу у творах Йозефа Рота / О.Коцюба // Науковий вісник Волинського національного університету імені Лесі Українки. Філологічні науки. - 2010. - № 8. C. 99-103. 
Кульчицький 1992 - Кульчицький О. Світовідчування українців /О.Кульчицький // Українська душа. - К., 1992. - С. 48-65.

Липа 1992 - Липа Ю. Призначення України /Ю.Липа. - Л., 1992. - 270 с.

Михайлин 1994. - Михайлин І. Воли і ясла (До філософської інтерпретації роману Панаса Мирного та Івана Білика «Хіба ревуть воли, як ясла повні?») /І.Михайлин // Збірник Харківського історико-філологічного товариства. Харків, 1994. - С. 61-73.

Онацький 1992 - Онацький Є. Українська емоційність / Є.Онацький // Українська душа. - К., 1992. - С. 36-47.

Панас Мирний та Іван Білик 1981. - Панас Мирний та Іван Білик. Хіба ревуть воли, як ясла повні? - К., 1981. -368 с.

Пономарів 1992 - Пономарів О. Стилістика сучасної української мови /О.Понамарів. - К., 1992. - 248 с.

Храмова 1992 - Храмова В. До проблем української ментальності / В.Храмов // Українська душа. - К., 1992. - С. 3-35.

Чижевський 1983 - Чижевський Д. Нариси з історії філософії на Україні /Д.Чижевський. - Мюнхен, 1983. - 175 с.

Шлемкевич 1992 - Шлемкевич М. Душа і пісня / М.Шлемкевич // Українська душа. - К., 1992. - С. 97-112.

Шлемкевич 1992 - Шлемкевич М. Загублена українська людина /М.Шлемкевич. K., 1992. $-168 \mathrm{c}$.

Стаття надійшла 18 вересня 2013 p. 